\title{
14. PALYNOLOGICAL STUDY OF SAMPLES FROM SITES 430, 431, 432, 433
}

\author{
E. V. Koreneva, Geological Institute of the U.S.S.R. Academy of Sciences, Moscow
}

\begin{abstract}
Samples from Sites $430,431,432$, and 433, DSDP Leg 55, on the Emperor seamounts, contain almost no spores or pollen of terrestrial plants. This testifies to the region's remoteness from land throughout the period of sediment formation. Lower Paleogene spores and pollen are present in small amounts in samples of Hole 433B lagoonal deposits.
\end{abstract}

\section{MATERIALS AND METHODS}

Forty-six samples from all Sites drilled on Leg 55 were analyzed (Figure 1).

The sediments were treated with 10 per cent $\mathrm{HCl}-$ depending on their lithologic and grain-size compositions - for dissolution of carbonates, boiled in 10 per cent $\mathrm{KOH}$ for dissociation of sediment, elutriated in pyrophosphate solution $\left(\mathrm{NO}_{4} \mathrm{P}_{2} \mathrm{O}_{7}\right)$, separated in a heavy liquid $\left(\mathrm{CdF}_{2}\right)$ with specific gravity 2.2 , and treated by the acetolysis technique. Release from silicates was accomplished with cold HF, and glycerine was added to the residue obtained. Fixed specimens were prepared from glycerine emulsion on glycerine gel. These specimens are stored in the collection of the Paleofloristic Laboratory of the Geological Institute of the USSR Academy of Sciences under No. GIN 3948. Each specimen has its own number.

Most specimens consist of carbonate, silicate, and volcanogenic pelagic sediments containing no terrigenous material. They are entirely devoid of pollen and spores.

Samples from Hole 433A, Cores 7 through 12, are mostly reef sand that likewise contain no spores or pollen.

Small amounts of lower Paleogene spores and pollen were recovered in three samples from Hole 433B, Cores 1 and 2 only. The samples yielded single spores from the families Pteridaceae, Schizaeaceae, Cyatheaceae, and Polypodiaceae (Plate 1); two pollen grains belonging to conifers from the Pinaceae Family; and one pollen grain of an angiosperm plant (Plate 2).

Identification was facilitated by reference to atlases and monographic descriptions of spores and pollen: Krutzsch $(1959,1962,1967)$, Elsik (1968), Zaklinskaya (1957).

\section{DISCUSSION}

The Emperor Seamounts lie between $40^{\circ}$ and $45^{\circ} \mathrm{N}$. Lat. and $170^{\circ}$ and $171^{\circ} \mathrm{E}$. Long. The distance to the nearest land, Kamchatka, is about $1700 \mathrm{~km}$, that to Japan about $2500 \mathrm{~km}$. No pollen or spores are supplied at present to the Emperor Seamounts region. The chain formed during the Late Cretaceous and Paleogene, and

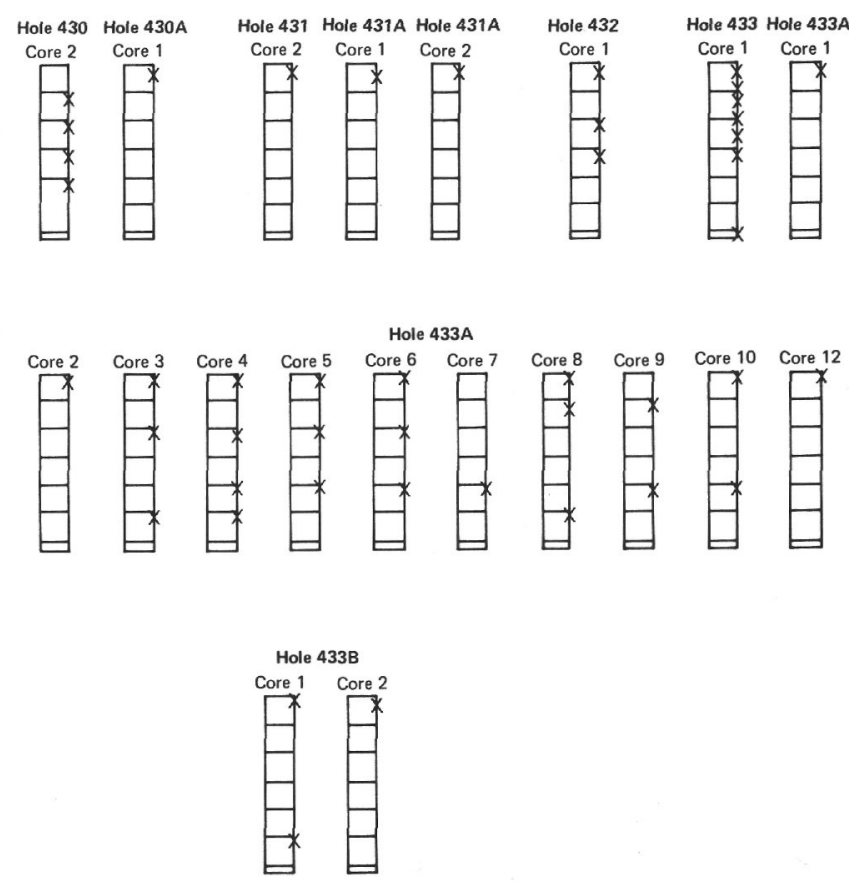

Figure 1. Locations of the samples.

consists of separate volcanic edifices with reefs formed on the basaltic base. In the Paleocene and early Eocene in the Emperor ridge system there existed a number of islands overgrown with tropical vegetation, fern-like, in the main. In shallow-water lagoons of the islands, coarse-grained reef sand accumulated. The sand consisted of washout products of reef and remains of organisms living in the lagoon: tests of benthic foraminifers, ostracodes, pelecypods, mollusks, and so forth.

Spores and pollen of plants growing on the islands were brought by wind into the lagoon and buried in sediments.

The concentration of pollen in lagoonal deposits of the islands is always very low because of the small area of the islands and the consequent insignificant supply of pollen and spores, and because of a high rate of accumulation of coarse-grained sediments in the lagoons (Koreneva, 1964). 
Subsidence resulted in disappearance of the islands from the surface in this part of the ocean. Accumulation of reefal sands devoid of pollen and spores (Cores 7 through 12 of Hole 433A) was proceeding in the shallow water after subsidence began, when the islands had disappeared under the water level. Since then, the supply of pollen and spores of terrestrial plants into sediments of this region has completely ceased.

\section{ACKNOWLEDGMENTS}

In conclusion, I would like to express my sincere gratitude to the chiefs and participants of DSDP Leg 55 for making available the material for palynological studies.

\section{REFERENCES}

Elsik, W. C., 1968. Palynology of a Paleocene Rockdale lignite, Milam County, Texas. II. Morphology and Taxonomy (end). Pollen et Spores, v. X, no. 3., pp. 599-664.
Koreneva, E. V., 1964. Pollen et spores from bottom sediments in the western part of the Pacific ocean. Acad. Nauk SSSR, Geol. Inst. Trudy, v. 109, pp. 1-88. (In Russian.)

Krutzsch, W., 1959. Micropaläontologische (sporenpalaontologische) Untersuchungen in der Braunkohpen des Geiseltaes, Geologie, v. 8, 21/22 pp. 1-425.

, 1962. Atlas der mittel-und jungtertiaren dispersen

Sporen- und Pollensowie der Mikroplanktonformen des Nordlichen Mitteleuropas: Berlin, Lieferung 1, pp. 1-108. 1967. Atlas der mittel- und jungtertiaren dispersen Sporen- und Pollensowie der Mikroplanktonformen des Nordlichen Mitteleuropas: Jena, Lieferungen 4 and 5, p. 142.

Thomson, P. W. and Pflug, H., 1953. Pollen und Sporen des mitteleuropäischen Tertiärs, Paläeontographica, v. 94 (B) pp. 1-138.

Zaklinskaya, E. D., 1957. Stratigraphic importance of gymnospermic pollen in Cenozoic deposits of Pavlodar-Irtish and northern Voraral areas, Akad. Nauk SSSR, Geol. Inst. Trudy, v. 6, pp. 1-219. (In Russian.)

1963. Angiosperm pollen and its role in the stratigraphy of the Upper Cretaceous and Paleogene, Akad. Nauk SSSR, Geol. Inst. Trudy, v. 74, p. 258. (In Russian.)

PLATE 1

All magnifications $\times 1000$.

Figures 1, 2 Faveotriletes verucatoides W.Kr., 1962, n. comb. Sample 433B-1-6, 100-102 cm. (my sample no. $1297 \mathrm{k} / \mathrm{m}$ ).

Figure 3 Leiotriletes wolffi W.Kr., 1962. Cyatheaceae.

Sample 433B-2-1, 64-66 cm.

(my sample no. $1298 \mathrm{k} / \mathrm{m}$ ).

Figures 4, 5 Trilites microvallatus W.Kr., 1967.

Sample 433B-2-1, 64-66 cm.

(my sample no. $1298 \mathrm{k} / \mathrm{m}$ ).

Figure $6 \quad$ Leiotriletes microadriennis W.Kr., 1959. Schizea-

ceae, cf. Lygodium.

Sample 433B-1-1, 25-27 cm.

(my sample no. $1296 \mathrm{k} / \mathrm{m}$ ).

Figure 7

Trilites sp. Pteridaceae cf. Pteris.

Sample 433B-1-6, 100-102 cm.

(my sample no. $1297 \mathrm{k} / \mathrm{m}$ ).

Figures 8, 9 Polypodiaceoisporites lusaticus W.Kr., 1967, n.

comb. Pteridaceae.

Sample 433B-1-1, 25-27 cm.

(my sample no. $1296 \mathrm{k} / \mathrm{m}$ ).

Figure 10 Echinosporis sp.

Sample 433B-2-1, 64-66 cm.

(my sample no. $1298 \mathrm{k} / \mathrm{m}$ ).

Figure $11 \quad$ Polypodidites secundus (R. Pot.) W.Kr., 1967.

Sample 433B-1-1, 25-27 cm.

(my sample no. $1296 \mathrm{k} / \mathrm{m}$ ). 


\section{PLATE 1}
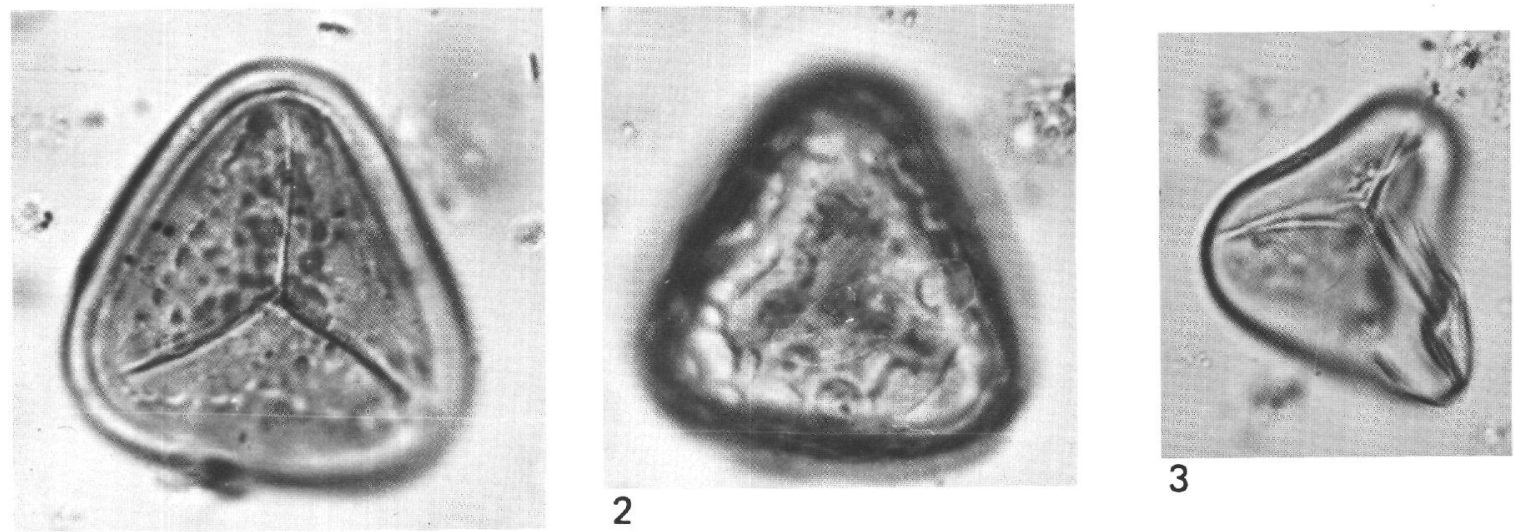

1

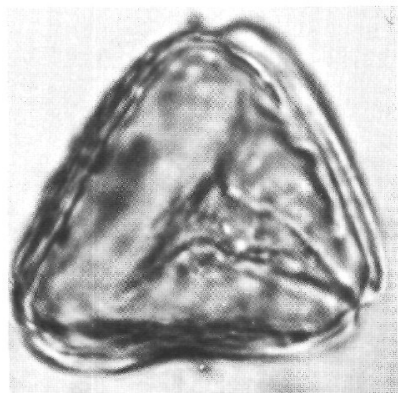

4
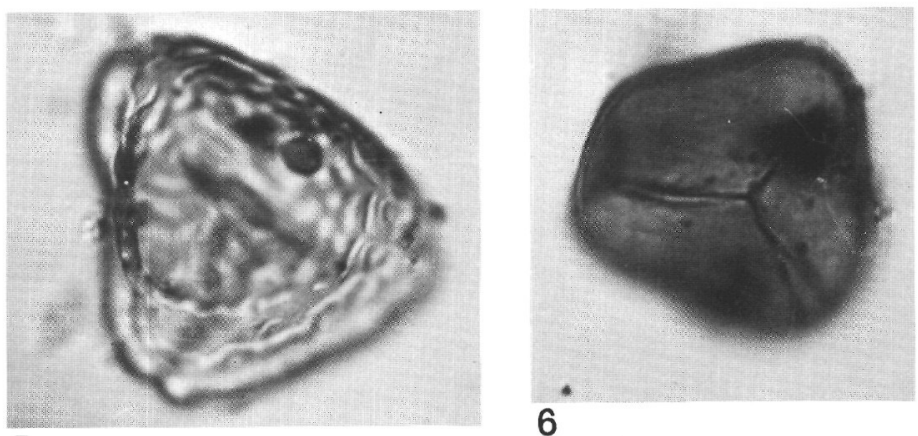

5
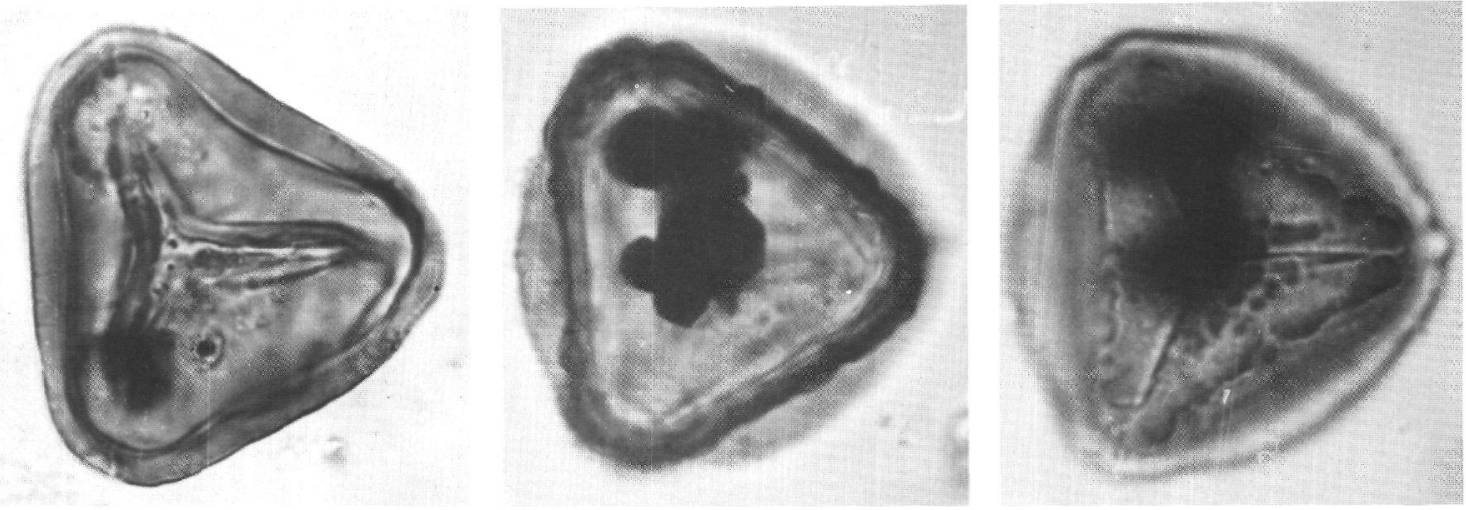

7

8

9
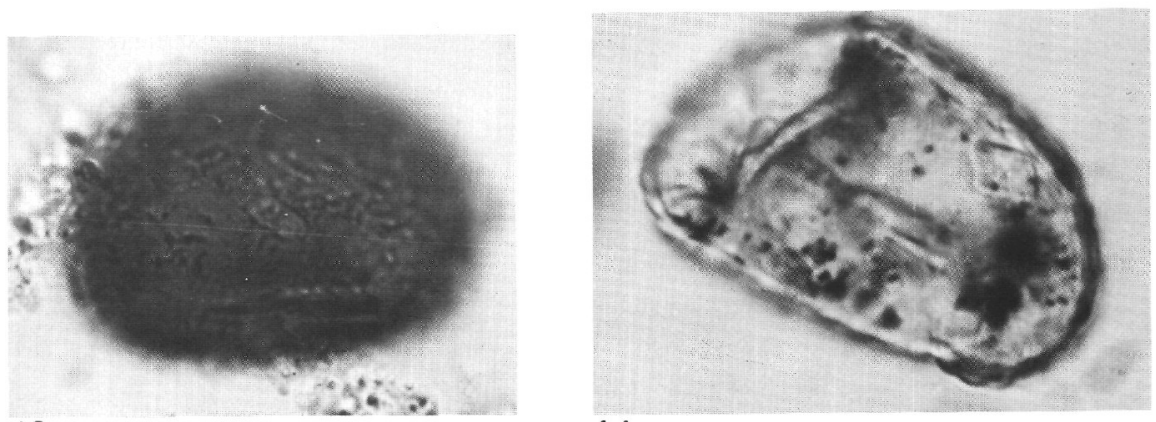

11 
PLATE 2

All magnifications $\times 1000$.

Figure 1 Pinaceae. cf. Picea.

Sample 433B-1-1, 25-27 cm.

(my sample no. $1296 \mathrm{k} / \mathrm{m}$ ).

Figure 2 Pinaceae.

Sample 433B-1-6, 100-102 cm.

(my sample no. $1297 \mathrm{k} / \mathrm{m}$ ).

Figure 3 Tricolporopollenites kruschii Tomson and Pflug, 1953.

Sample 433B-2-1, 64-66 cm.

(my sample no. $1298 \mathrm{k} / \mathrm{m}$ ). 
PLATE 2

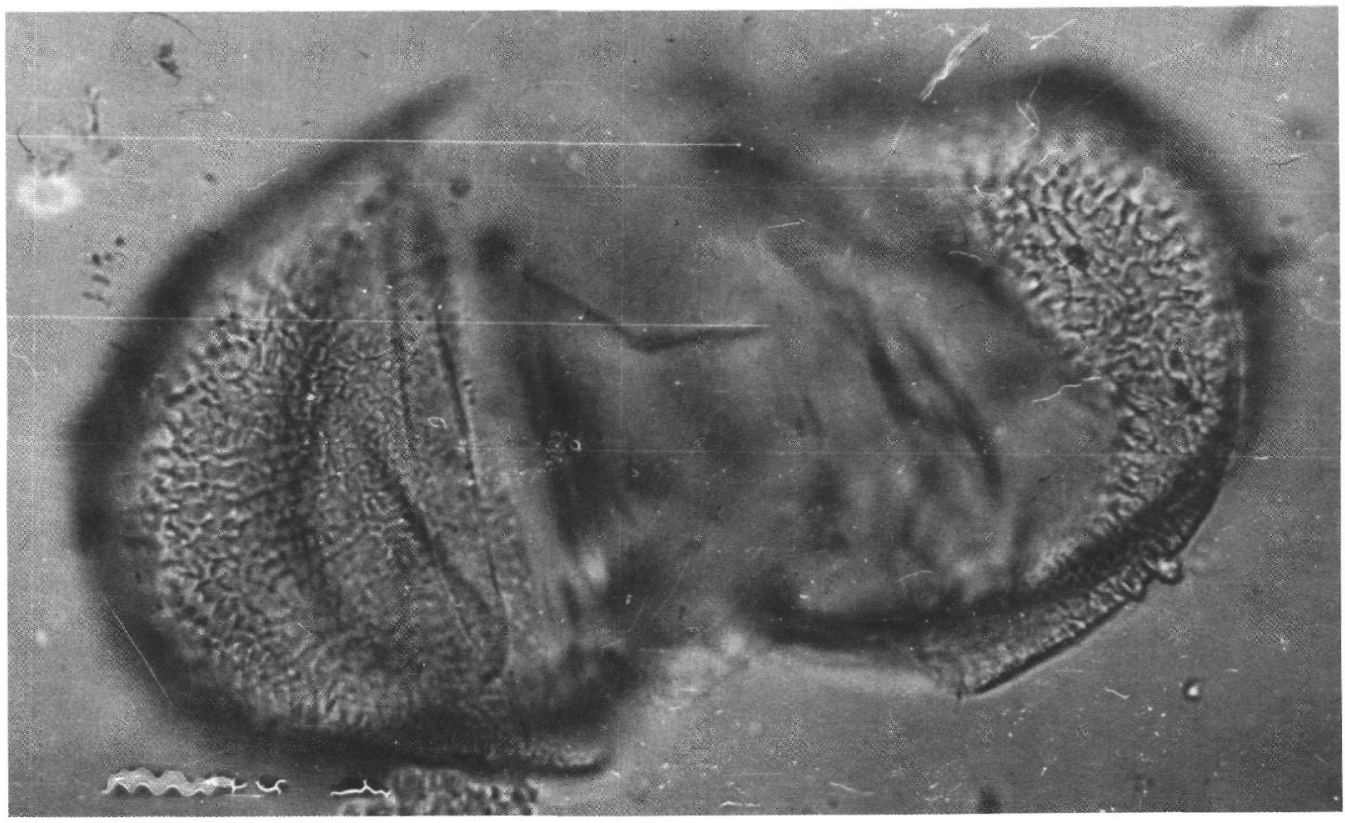

1
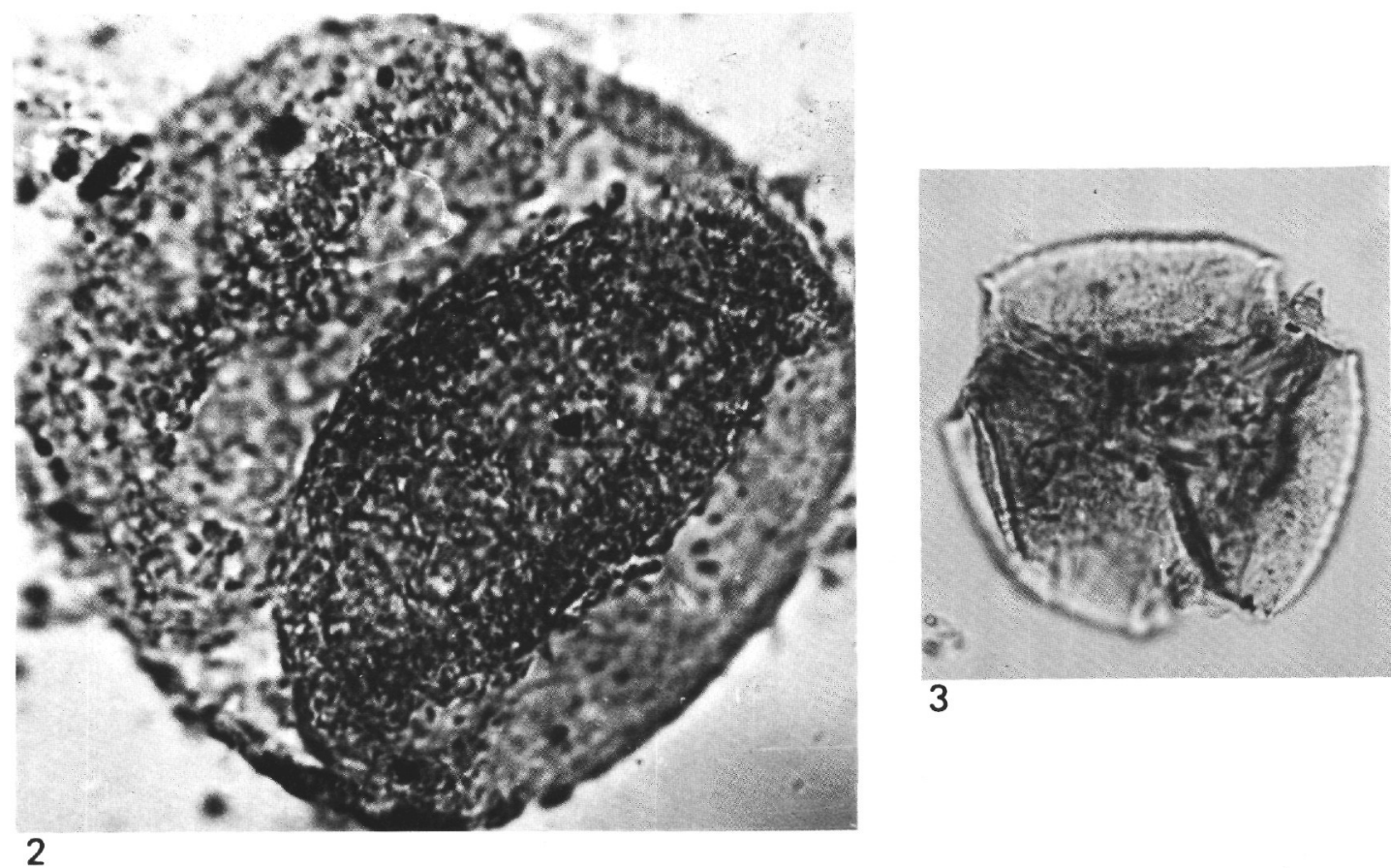